\title{
Antioxidant Activity of Cashew Nut Shell Liquid (CNSL) Derivatives on the Thermal Oxidation of Synthetic cis-1,4-Polyisoprene
}

\section{Francisco Helder A. Rodrigues, ${ }^{a}$ Judith P. A. Feitosa, ${ }^{*},{ }^{a}$ Nágila M. P. S. Ricardo, ${ }^{a}$ Francisco Célio F. de França ${ }^{a}$ and José Oswaldo B. Carioca}

\author{
${ }^{a}$ Departamento de Química Orgânica e Inorgânica, Universidade Federal do Ceará, CP 12200, \\ 60455-760 Fortaleza-CE, Brazil \\ ${ }^{b}$ Departamento de Tecnologia de Alimentos, Universidade Federal do Ceará, CP 12168,
} 60455-760 Fortaleza-CE, Brazil

\begin{abstract}
LCC (Líquido da Castanha de Caju), ou CNSL (Cashew Nut Shell Liquid), é uma mistura de meta-alquilfenóis, que variam no grau de insaturação do grupo ligado ao núcleo benzênico. A degradação térmica do poli(1,4-cis-isopreno) sintético a $140{ }^{\circ} \mathrm{C}$ foi estudada na presença do LCC técnico e de alguns derivados (cardanol, cardanol hidrogenado e cardanol hidrogenado e alquilado), através de FTIR. A quantidade de grupamentos $\mathrm{OH} / \mathrm{OOH}$ e $\mathrm{C}=\mathrm{O}$ formados e de $\mathrm{C}=\mathrm{C}$ consumidos foi determinada durante a degradação. Todos os materiais aumentaram o tempo de indução e diminuíram as constantes aparentes de velocidade. Com base nos parâmetros cinéticos, a ordem de atividade antioxidante é: $\mathrm{LCC}>>$ cardanol $\cong$ cardanol hidrogenado e alquilado > cardanol hidrogenado. O efeito do LCC pode ser atribuído à contribuição extra de seus outros componentes, além do cardanol, e à insaturação na longa cadeia lateral. Essa maior atividade é importante, considerando que o LCC tem mais baixo custo do que seus derivados.
\end{abstract}

CNSL is a mixture of meta-alkylphenols with variable degree of unsaturation attached to the benzene ring. The kinetic study of the thermal degradation at $140{ }^{\circ} \mathrm{C}$ of synthetic cis-1,4polyisoprene film, in the presence of technical CNSL and some derivatives (cardanol, hydrogenated cardanol and alkylated hydrogenated cardanol) was carried out by FTIR. The amount of $\mathrm{OH} / \mathrm{OOH}$ and $\mathrm{C}=\mathrm{O}$ formed and also of $\mathrm{C}=\mathrm{C}$ consumed during the degradation was determined. All materials increase the induction period and decrease the apparent rate constants of thermal-oxidation. Based on kinetic parameters, the order of antioxidant activity was: CNSL $>>$ cardanol $\cong$ hydrogenated and alkylated cardanol $>$ hydrogenated cardanol. The effect of CNSL could be attributed to the extra contribution of the other components besides cardanol and to the unsaturation on the long side chain. This greater activity is important because CNSL is much more cost effective than its derivatives.

Keywords: CNSL, phenol, polyisoprene, thermal oxidation, antioxidant

\section{Introduction}

Cashew nut shell liquid (CNSL) is a unique natural source for unsaturated long-chain phenols. It is a cheap and renewable material, obtained as a by-product of the cashew industry. CSNL by itself is useful as insecticidal, fungicidal, anti-termite and medicinal applications. ${ }^{1}$ It can be used as starting material for organic synthesis ${ }^{2}$ and replaces phenol in many instances with equivalent or better results. ${ }^{1}$ Resins derived from CNSL are widely employed in the field of friction materials, automobiles, surface

* e-mail: judith@dqoi.ufc.br coating, adhesives, laminates, rubber compounding, and have several miscellaneous applications. ${ }^{1}$ The most attractive consideration for CNSL use as an industrial product can be its low cost, abundant availability, and its chemically reactive nature.

On the basis of the mode of extraction from cashew nut shell, CNSL is classified into two types: solvent-extracted CNSL and technical CNSL. A typical solvent-extracted material contains anacardic acid (60-65\%), cardol (15$20 \%$ ), cardanol $(10 \%)$, and traces of 2-methyl cardanol (Figure 1). ${ }^{3}$ Technical CNSL is obtained by roasting shell at $180-200{ }^{\circ} \mathrm{C}$. The anacardic acid is thermally unstable and is easily decarboxylated during the extraction process 
by heating and then transformed into cardanol. Technical CNSL contains mainly cardanol (60-65\%), cardol (15$20 \%$ ), polymeric material (10\%), and traces of 2-methyl cardol. ${ }^{3}$ Depending on the conditions of the roasting process, the composition of the technical CNSL can change and reach higher cardanol content (83-84\%), less cardol (8-11\%) and maintain polymeric material as $10 \%$ and 2-methyl cardol content as $2 \% .^{4}$

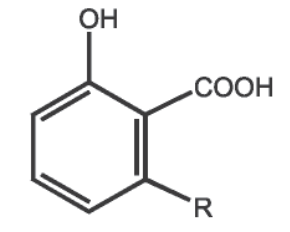

Anacardic Acid

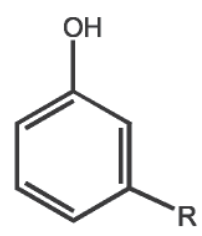

Cardanol

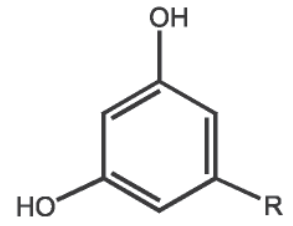

Cardol

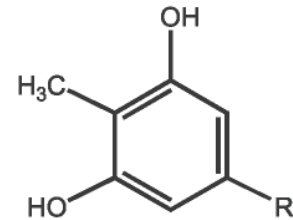

2-Methyl cardol

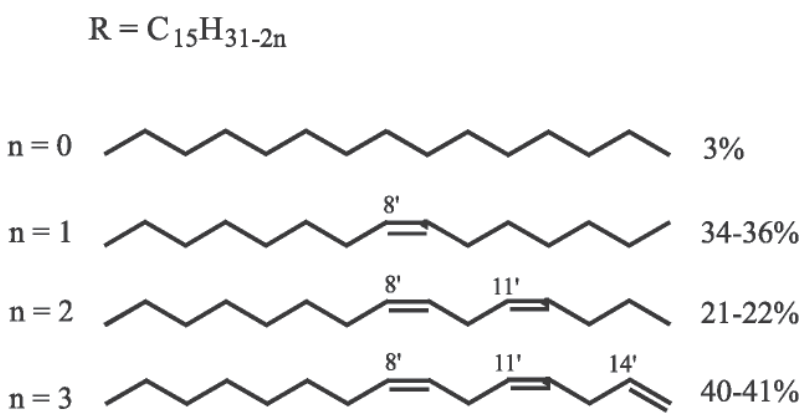

Figure 1. Structures of CNSL constituents.

The use of natural antioxidants is well established. Hindered phenolic compounds $(\mathrm{ArOH})$ represent the major family of both natural and synthetic antioxidants. ${ }^{5}$ They are an excellent additive in polymers and lubricants. ${ }^{6}$ In general, efficient phenol antioxidants have substituents in ortho- and/ or para-positions. The antioxidant effect is related to the electron donating nature and the steric effect of the substituent(s). ${ }^{7}$ The electron-donating effect can enhance the electron density at the oxygen of the phenol, resulting in a high radical-trapping rate. The steric effect prevents phenoxy radicals from coupling and to increase the number of trapped peroxy radicals. ${ }^{7}$ CNSL is a mixture of hindered phenols with a long alkyl substitution at the meta-position. Despite not displaying substitution in the preferential ortho and/or para-position, the antioxidant activity of CNSL or its derivatives, in special phosphorylated, in natural rubber vulcanizates has been reported. ${ }^{8-13}$ The presence of phosphate group, ${ }^{12}$ the formation of a network bound antioxidant ${ }^{11}$ or the formation of phenolic sulfides in situ during the vulcanization ${ }^{13}$ have been used to explain the antioxidant activity of CNSL derivatives in natural rubber vulcanizates. The steric effect, due to long tail substituent, has been also reported as an important factor. ${ }^{14}$

The inexistence of studies about the effect of CNSL on the oxidation of natural rubber or synthetic polyisoprene during processes other than the vulcanization and the possibility of new uses of this material motivated the present work. Its objective is to determine the antioxidant activity of CNSL and some derivatives on the thermal oxidation of the synthetic cis-1,4-polyisoprene films at $140{ }^{\circ} \mathrm{C}$. Technical CNSL, cardanol, hydrogenated cardanol and alkylated hydrogenated cardanol (Figure 2) were tested. The influence of long tail unsaturation, alkylation on ortho-position, and synergistic effect of these phenolic compounds on their antioxidant activity were examined.

\begin{tabular}{cc} 
ArOH & $\mathrm{R}^{1}$ \\
\hline $\begin{array}{c}\text { Hydrogenated } \\
\text { Cardanol } \\
\begin{array}{c}\text { Alkylated } \\
\text { Hydrogenated } \\
\text { Cardanol }\end{array}\end{array}$ \\
\hline
\end{tabular}

Figure 2. Structure of antioxidant species.

\section{Experimental}

\section{Materials and methods}

The synthetic cis-1,4-polyisoprene was provided by Aldrich Chemical Company and kept at low temperature $\left(\sim-10^{\circ} \mathrm{C}\right)$. The cashew nut shell liquid derivatives, such as the hydrogenated cardanol (Hcardanol), and the alkylated hydrogenated cardanol (HAlkcardanol) were supplied by PADETEC (Parque de Desenvolvimento 
Tecnológico do Estado do Ceará). The technical CNSL was supplied by CIONE cashew industry. Cardanol was purified from the technical CNSL following the method described by Paramashivappa et al. ${ }^{15}$ Technical CNSL, cardanol, Hcardanol and HAlkcardanol were tested with concentrations of $1,2,3$ and $5 \%(\mathrm{~m} / \mathrm{m})$.

Film preparation

The films were prepared from cis-1,4-polyisoprene by successive casting and solvent evaporation from polymer solution $\left(2 \mathrm{~g} \mathrm{dL}^{-1}\right.$ in $\left.\mathrm{CHCl}_{3}\right)$ on PTFE film (thickness of $0.10 \mathrm{~mm}$ ) in the presence and in the absence of CNSL and its derivatives. Before being deposited over the PTFE film, the rubber solution was homogenized by stirring for approximately $12 \mathrm{~h}$. Subsequently, CNSL and its derivatives were added directly into the polymer solution and stirred for further $12 \mathrm{~h}$. The evaporation lasted for $24 \mathrm{~h}$ in order to assure that the solvent $\left(\mathrm{CHCl}_{3}\right)$ had been completely eliminated. The thickness of the films was in the range of 50-60 $\mu \mathrm{m}$ confirmed by absorbance at $1447 \mathrm{~cm}^{-1}$, assigned to $\mathrm{CH}_{2}$ deformation vibration and determined as directly proportional to film thickness up to $80 \mu \mathrm{m}$.

\section{Film heating}

The rubber films were heated both in the presence and in the absence of CNSL derivatives, using an oven Model19 Thelco, in a constant temperature of $140 \pm$ $1{ }^{\circ} \mathrm{C}$ in atmospheric air and pressure. Each film was heated during time intervals of $10 \mathrm{~min}$ followed by Fourier Transformed Infrared (FTIR) measurements. At least three films of each antioxidant concentration were heated and analyzed. The results are the average values of these replicates.

\section{Infrared analysis}

The FTIR spectra were obtained in a Shimadzu model 8300 spectrometer. Taking into account that polyisoprene degradation produces volatile materials, and thus reduces film thickness, a normalization procedure was adopted. The band at $1447 \mathrm{~cm}^{-1}$ was used as an internal standard for the calculation of relative absorbance consider as a normalized value. ${ }^{16}$

\section{Thermogravimetric analyses}

Thermogravimetric analyses were performed in a Shimadzu TGA equipment, under $\mathrm{N}_{2}$ atmosphere, at 50

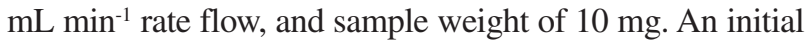

heating at $10{ }^{\circ} \mathrm{C} \mathrm{min}-1$ was applied until the temperature of $140{ }^{\circ} \mathrm{C}$ was reached. An isotherm curve was then obtained up to 300 minutes. Rubber film without antioxidant and with $5 \%(\mathrm{~m} / \mathrm{m})$ of CNSL and its derivatives were heated.

\section{Results and Discussion}

\section{Effect of CNSL derivative structure}

The FTIR spectrum for thermaly-oxidated rubber presented three important bands, as verified in previous publications: ${ }^{16}$ at $835 \mathrm{~cm}^{-1}$, assigned to out of plane bending of $=\mathrm{C}-\mathrm{H}$; at $3450 \mathrm{~cm}^{-1}$, attributed to stretching of $\mathrm{OH}$ and/or $\mathrm{OOH}$; and $1720 \mathrm{~cm}^{-1}$, due to stretching of $\mathrm{C}=\mathrm{O}$. The presence of $\mathrm{OH} / \mathrm{OOH}$ and $\mathrm{C}=\mathrm{O}$ groups corresponds to products of degradation such as alcohols, carboxylic acid, hydroperoxides, aldehyde, ketone, ether or ester. ${ }^{17}$ Figure $3 \mathrm{~A}$ shows the relative absorbance evolution, $\mathrm{Abs}_{\text {rel }}$, of these bands for the polyisoprene oxidation without antioxidant. An initial region can be noticed, where changes in the $\mathrm{Abs}_{\text {rel }}$ do not occur. The subsequent region shows the formation of $\mathrm{OH} / \mathrm{OOH}$ and $\mathrm{C}=\mathrm{O}$ groups and a concomitant consumption of $=\mathrm{C}-\mathrm{H}$, and indirectly of $\mathrm{C}=\mathrm{C}$ bonds of isoprene units. The band at $835 \mathrm{~cm}^{-1}$ will be considered hereafter as related to the double bond.

The formation of $\mathrm{OH} / \mathrm{OOH}$ and the consumption of $\mathrm{C}=\mathrm{C}$, in the beginning of thermal oxidation, obey a first order kinetics. ${ }^{18}$ The curve relative to the formation of $\mathrm{C}=\mathrm{O}$ group shows an auto-acceleration feature and follows the parabolic law $\left([\mathrm{C}=\mathrm{O}]=\mathrm{kt}^{2}\right) .{ }^{18}$ The equations utilized for the determination of the induction period $\left(\tau_{\mathrm{i}}\right)$ and the apparent rate constants $(k)$, were reported in previous study. ${ }^{16}$

The presence of $5 \%(\mathrm{~m} / \mathrm{m})$ of technical CNSL displaces all curves for longer times of reaction (Figure $3 \mathrm{~B}$ ) in comparison with the curves in Figure 3A. This is indicative of a delay on the start of the thermal oxidation and an increase in the induction period when the CNSL is added. After the induction period, the process is faster and is similar to the one observed for pure polyisoprene. The effects of the addition of all CNSL derivatives (cardanol, Hcardanol and HAlkcardanol) over the thermal oxidation of polyisoprene were similar to those observed with rubber in the presence of CNSL, but at different degree.

Table 1 shows the apparent rate constant and the induction period for polyisoprene in the absence and in the presence of $5 \%(\mathrm{~m} / \mathrm{m})$ of technical CNSL and its derivatives. Each value represents the average of at least three replicates. An average induction period was calculated from the individual induction period and represents the process as a whole. The addition of alkylated hydrogenated cardanol (HAlkcardanol) for each measured 

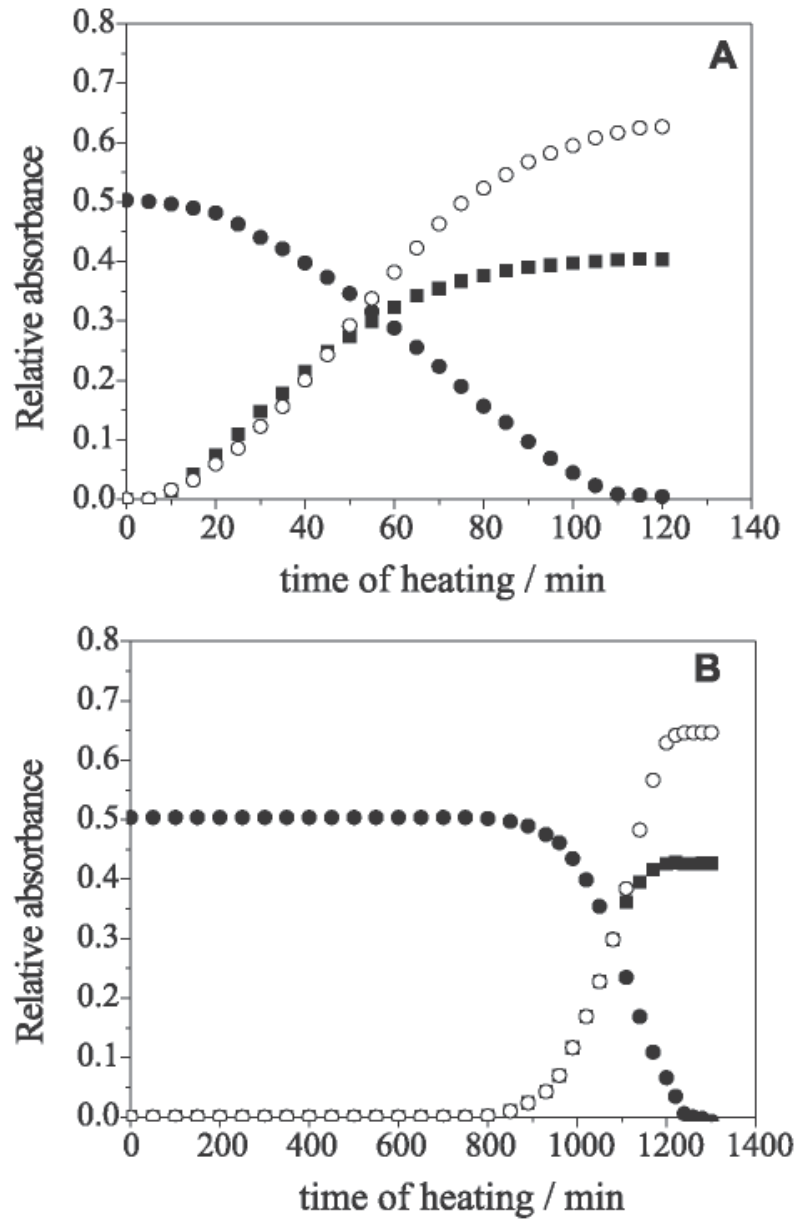

Figure 3. Kinetics of thermal-oxidation of polyisoprene film at $140{ }^{\circ} \mathrm{C}$. (A) in absence of antioxidant; (B) in the presence of $5 \%$ of technical CNSL. Consumption of $\mathrm{C}=\mathrm{C}(\boldsymbol{O}) 835 \mathrm{~cm}^{-1}$; formation of $\mathrm{C}=\mathrm{O}(\boldsymbol{\square}) 1720$ $\mathrm{cm}^{-1}$; formation of $\mathrm{OH} / \mathrm{OOH}(\mathrm{O}) 3450 \mathrm{~cm}^{-1}$.

phenol concentration caused higher induction periods and smaller apparent rate constants than the addition of hydrogenated cardanol (Hcardanol) at the same $\mathrm{ArOH}$ concentration. The antioxidant activity of HAlkcardanol is greater than that of nonalkylated cardanol (Hcardanol).

The basic mechanism of autooxidation of polyisoprene (RH) includes four steps: initiation, propagation, chain branching and termination. One important reaction in the propagation step is the formation of $\mathrm{RO}_{2}{ }^{*}$, also formed in chain branching step. ${ }^{19}$ Phenolic compounds (ArOH) are chain breaking antioxidants (interrupt the chain reaction) well known as a radical scavengers that trap peroxy radicals $\left(\mathrm{RO}_{2}{ }^{\circ}\right)$. The manifested activity is due to their higher reactivity towards these radicals. While reducing the $\mathrm{RO}_{2}{ }^{\cdot}$ radicals in reaction (1), phenols convert themselves into resonance-stabilized phenoxy radicals (ArO*). To be effective the phenoxy radical must also reacts slowly with substrate $\mathrm{RH}$ and rapidly with $\mathrm{RO}_{2} \cdot$. In the oxidation chain termination reaction (2), $\mathrm{ArO}^{\bullet}$ are generally consumed to produce non radical products: ${ }^{20}$

$\mathrm{RO}_{2}^{\bullet}+\mathrm{ArOH} \rightarrow \mathrm{RO}_{2} \mathrm{H}+\mathrm{ArO}^{\bullet}$

$\begin{aligned} & \mathrm{RO}_{2}{ }^{\circ}+\mathrm{ArO}^{*} \\ & \mathrm{ArO}^{*}+\mathrm{ArO}^{\cdot}\end{aligned} \mid->$ non radical products

In the HAlkcardanol, a tert-butyl substituent was added in the ortho position of the ring (Figure 2). This electron donating substituent increases the electron density at the oxygen of the phenol and stabilizes the phenoxy radicals, resulting in a high radical-trapping rate. ${ }^{7}$ Additionally, an increase in the size of the ortho substituent causes a decrease in the O-H bond strength, thus improving phenol reactivity, and also leading to a more pronounced steric hindrance in the reaction of the peroxy radical with the functional center. ${ }^{21}$

The higher antioxidant activity of cardanol (higher $\tau_{\mathrm{i}}$ and smaller $k$ ) compared with Hcardanol, both added at $5 \%$ concentration (Table 1) indicates that the unsaturation on the long side chain could be an important factor. Recently, Ohkatsu et al. ${ }^{22}$ proposed that some phenols with allyl substituents could trap both alkyl and peroxy radicals, and increase antioxidant activity, taking into account that autoxidation includes these two radicals as chain carriers. The mechanism of trapping rubber radicals $\left(\mathrm{R}^{*}\right)$ is suggested in Figure 4, similar to that proposed by the authors. ${ }^{22}$ To assure a better understanding of those mechanism, the long side chain of cardanol $\left(\mathrm{R}=\mathrm{C}_{15} \mathrm{H}_{31-2 \mathrm{n}}\right)$ was considered as having only one unsaturation $(\mathrm{n}=1)$. Steps II and IV are probably difficult to occur considering the high molar mass of the rubber radical. Another contribution to lesser antioxidant activity of hydrogenated cardanol could be the remains of metal catalyst $(\mathrm{Pd})$, used during the hydrogenation reaction. Metals are known to be pro-oxidant of polyolefins. ${ }^{23}$

Table 1. Kinetic parameters for thermal oxidation at $140{ }^{\circ} \mathrm{C}$ of cis-polyisoprene in the absence and in the presence of $5 \%$ of antioxidant (ArOH) from cashew nut shell liquid

\begin{tabular}{|c|c|c|c|c|c|c|c|}
\hline \multirow[t]{2}{*}{$\mathrm{ArOH}$} & \multicolumn{4}{|c|}{ Induction period, $\tau_{\mathrm{i}}(\min )$} & \multicolumn{3}{|c|}{ Apparent rate constant, $k$} \\
\hline & $\mathrm{OH} / \mathrm{OOH}$ & $\mathrm{C}=\mathrm{O}$ & $\mathrm{C}=\mathrm{C}$ & Average value & $k_{\mathrm{OH} / \mathrm{OOH}} \times 10^{3}\left(\mathrm{~min}^{-1}\right)$ & $k_{\mathrm{C}=\mathrm{O}} \times 10^{6}\left(\mathrm{~min}^{-2}\right)$ & $k_{\mathrm{C}=\mathrm{C}} \times 10^{3}\left(\mathrm{~min}^{-1}\right)$ \\
\hline none & 23 & 19 & 21 & $21 \pm 2$ & 21 & 113 & 20 \\
\hline CNSL & 923 & 876 & 906 & $902 \pm 17$ & 4.2 & 0.47 & 4.1 \\
\hline cardanol & 392 & 360 & 378 & $377 \pm 11$ & 5.4 & 2.6 & 5.3 \\
\hline Hcardanol & 134 & 114 & 124 & $124 \pm 7$ & 8.4 & 9.3 & 7.4 \\
\hline HAlkcardanol & 260 & 249 & 251 & $253 \pm 5$ & 6.3 & 4.8 & 5.9 \\
\hline
\end{tabular}




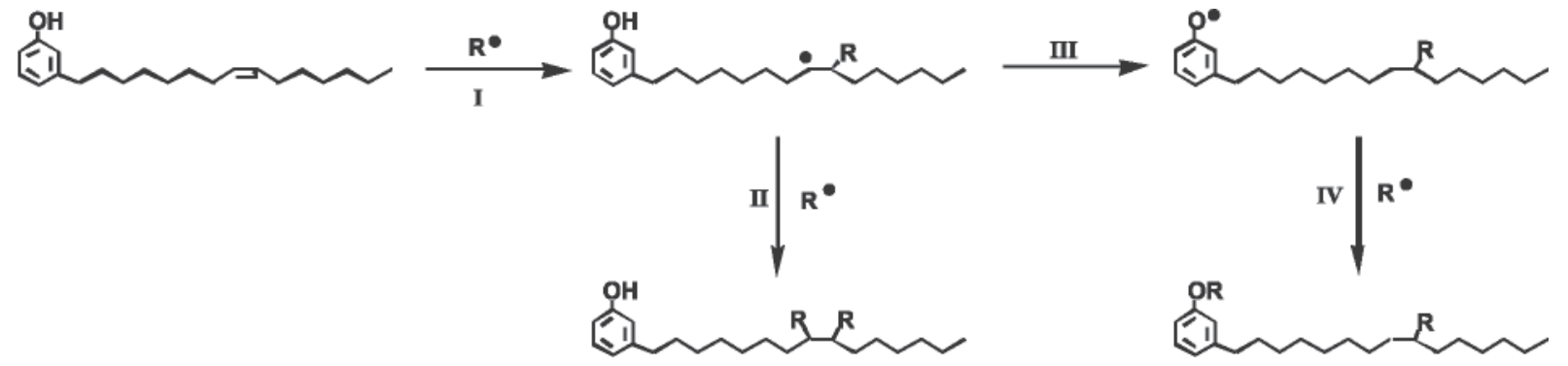

Figure 4. Suggested mechanism of cooperative action of hydroxyl and allyl groups in trapping rubber radicals $\left(\mathrm{R}^{*}\right)$.

The positive effect of ortho substitution verified on HAlkcardanol seems not to be strong enough to overcome the negative effects of elimination of the unsaturation on the long side chain of cardanol and the possible presence of metal from the remain catalyst.

Technical CNSL at 5\% concentration was the material that presented the highest antioxidant activity over the thermal oxidation at $140{ }^{\circ} \mathrm{C}$ of synthetic polyisoprene. This could be due to the extra or synergistic contribution of others CNSL components besides cardanol (cardol, 2-methyl-cardol and polymerized material). ${ }^{3,4}$ Cardol is known to contribute more towards the antioxidant activity of CNSL than cardanol. ${ }^{13}$

One important parameter in the antioxidant activity is the molar mass. Low molar mass antioxidants are easily lost from polymer through migration, evaporation, and extraction. This physical loss of antioxidants constitutes a major concern in the long-term use of polymers or when high temperature is employed. ${ }^{24}$ The new tendency to prevent this problem and guarantee their performance is the production of polymerbound antioxidants. ${ }^{24}$ The presence of about $10 \%$ of polymerized and compatible material, normally present in the technical CNSL, ${ }^{3}$ could decrease the migration of this antioxidant to the surface, reduce its volatilization and retain the antioxidant activity during heating.

Table 2 presents the mass loss of polyisoprene films in absence and in the presence of $5 \%$ of CNSL and its derivatives after isothermal heating at $140{ }^{\circ} \mathrm{C}$ by 150 and 300 minutes. Technical CNSL is the material more volatilized, especially after $300 \mathrm{~min}$ of heating. This means that part of the added CNSL migrates to the surface and is lost by volatilization. Even so, it presents the highest antioxidant activity. Difference in ArOH volatilization could not explain the higher activity of cardanol in comparison with HAlkcardanol, once the mass loss of HAlkcardanol is significantly smaller than that of cardanol.

Effect of antioxidant concentration on the induction period

Figure 5 shows the effect of $\mathrm{ArOH}$ concentration on the induction period $\left(\tau_{\mathrm{i}}\right)$ of the thermal oxidation of
Table 2. Mass loss of polyisoprene films in the absence and in the presence of $5 \%$ of antioxidants during 150 and 300 minutes of heating at $140^{\circ} \mathrm{C}$ in atmosphere of nitrogen

\begin{tabular}{lcc}
\hline \multirow{2}{*}{$\mathrm{ArOH}$} & \multicolumn{2}{c}{ Mass loss $(\% \mathrm{~m} / \mathrm{m})$} \\
\cline { 2 - 3 } & $150 \mathrm{~min}$ & $300 \mathrm{~min}$ \\
\hline CNSL & 0.48 & 0.83 \\
cardanol & 0.52 & 0.62 \\
Hcardanol & 0.44 & 0.46 \\
HAlkcardanol & 0.11 & 0.12 \\
\hline
\end{tabular}

polyisoprene. The behavior observed for $5 \%$ of antioxidants happens in lower concentrations (1, 2 and $3 \%$ ), but at a lower intensity.

Cibulková et al. ${ }^{25}$ considered that a better estimation of the antioxidants activity can be obtained using the ratio of the induction period of stabilized polymer, $\tau_{\mathrm{i}}(\mathrm{P}+\mathrm{ArOH})$, and unstabilized polymer, $\tau_{\mathrm{i}}(\mathrm{P})$, defined as the protection factor (PF).

$\mathrm{PF}=\frac{\tau_{\mathrm{i}}(\mathrm{P}+\mathrm{ArOH})}{\tau_{\mathrm{i}}(\mathrm{P})}$

To normalize the PF taking into account the molar mass, an effectiveness parameter was proposed: AEM.

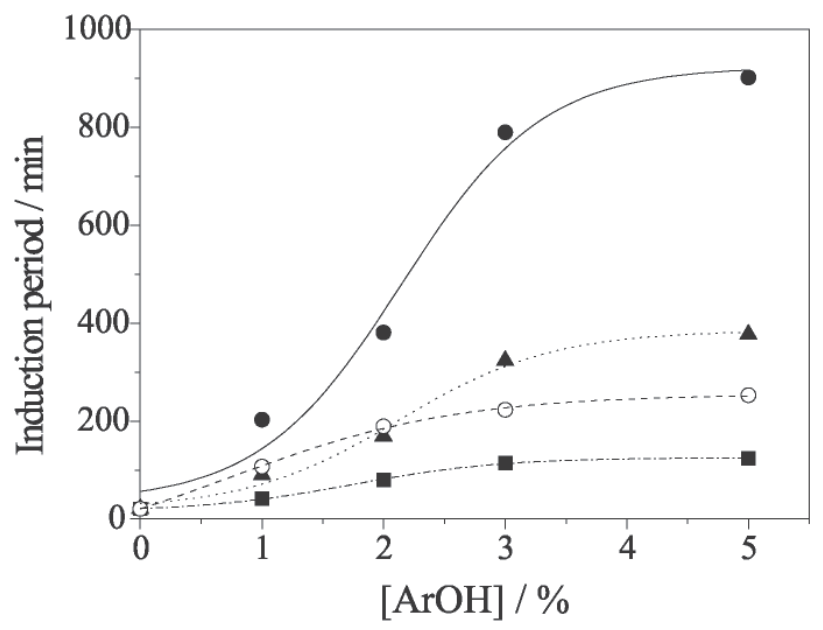

Figure 5. Effect of the antioxidant concentration on the induction period of the thermal oxidation of polyisoprene at $140{ }^{\circ} \mathrm{C}$. Antioxidants: Hcardanol ( $\square$ ); Cardanol ( $\mathbf{\Delta})$; HAlkcardanol (O); Technical CNSL(O). 
$\mathrm{AEM}=\frac{\mathrm{PF}-1}{m}$

where $m$ is the concentration of antioxidant in the polymer matrix expressed in mol $\mathrm{kg}^{-1}$.

Figure 6 shows the dependence of antioxidant effectiveness on the antioxidant concentration. Molar mass of cardanol, Hcardanol and HAlkcardanol were considered as $0.302 ; 0.304$ and $0.360 \mathrm{~kg} \mathrm{~mol}^{-1}$. Molar mass of technical CNSL was determined based on its average composition as $0.306 \mathrm{~kg} \mathrm{~mol}^{-1}$. CNSL and cardanol present a maximum $\mathrm{AEM}$ value at $\mathrm{ArOH}$ concentration around $3 \%$. Above and below this concentration the antioxidant effectiveness decreases. Hcardanol also presents the same tendency, but in a smaller intensity. On the other hand, HAlkcardanol shows a different behavior, with AEM value diminishing with increasing concentration and a tendency of stabilization at concentration higher than $5 \%$.

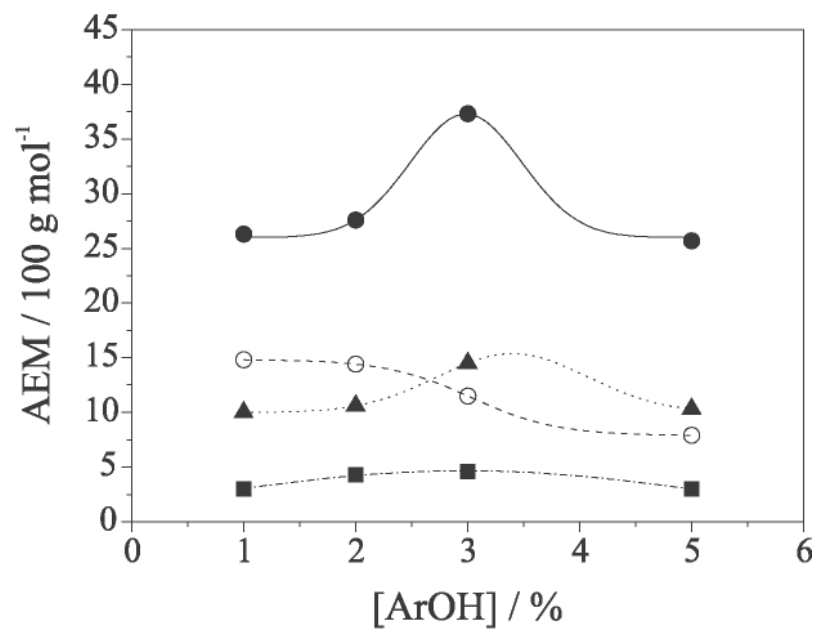

Figure 6. Effect of the antioxidant concentration on its effectiveness over thermal oxidation of polyisoprene at $140{ }^{\circ} \mathrm{C}$. Antioxidants: Hcardanol (ם); Cardanol ( $\mathbf{\Delta})$; HAlkcardanol (O); Technical CNSL( $)$.

Decarboxylated CNSL, that is the technical CNSL, can protect natural rubber vulcanizates against autooxidation when used in $2 \% .{ }^{13}$ Maximum antioxidant activity of phosphorylated CNSL (PCNSL) in polyethylene was observed in formulation containing $2 \%$ of this material. ${ }^{14}$ However, when PCNSL was added in vulcanization of natural rubber, the improved resistance to thermal oxidation ageing and decomposition was highest at the concentration of $20 \%{ }^{8}$

Effect of antioxidant concentration on the apparent rate constants

Figure 7 shows that the apparent rate constants of the thermal-oxidation of the polyisoprene, taken here as the rate constant of the consumption of carbon double bonds
$\left(\mathrm{k}_{\mathrm{C}=\mathrm{C}}\right)$, is reduced when the concentration of each $\mathrm{ArOH}$ increases. This is indicative that as soon as the polyisoprene oxidation begins, after the induction period, it occurs at a lower rate in the presence of antioxidants than in their absence. The curves present a similar behavior for all studied antioxidants. The rate constant reduction decreases as more $\mathrm{ArOH}$ are added to polymer. There is a greater reduction for concentrations below 3\%, while there was a tendency to stabilization for greater concentrations. Similar behavior was observed for the other rate constants $\left(\mathrm{k}_{\mathrm{OH} / \mathrm{OOH}}\right.$ and $\left.\mathrm{k}_{\mathrm{C}=\mathrm{O}}\right)$ whose curves are not shown.

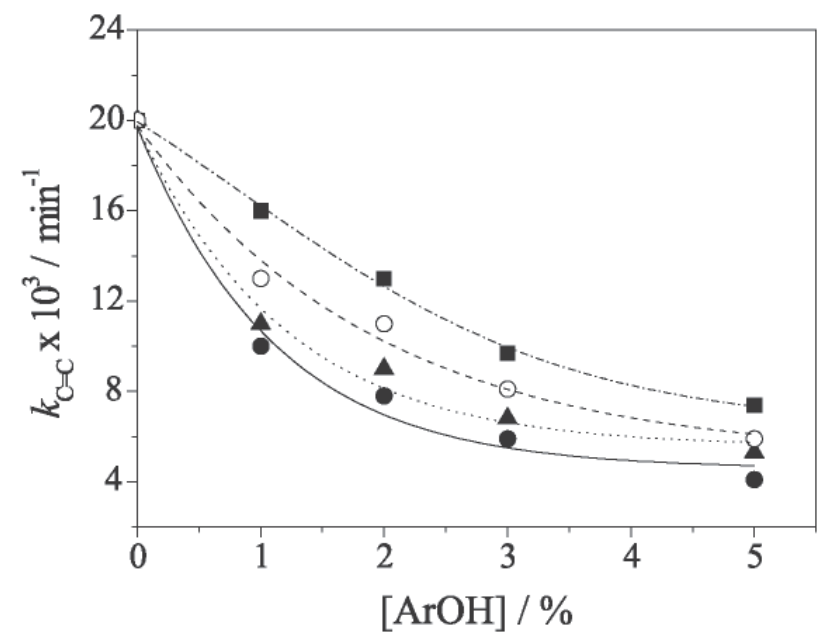

Figure 7. Effect of the antioxidant concentration on the apparent rate constant of $\mathrm{C}=\mathrm{C}$ consumption during thermal oxidation of polyisoprene at $140{ }^{\circ} \mathrm{C}$. Antioxidants: Hcardanol (ם); Cardanol ( $\left.\boldsymbol{\Delta}\right)$; HAlkcardanol (O); Technical CNSL(O).

The ability of hydrogenated cardanol in decreasing the rate of oxidation reactions is smaller than for the others antioxidants that have been studied. This material showed the least antioxidant effectiveness, based on induction period (Figure 6). Hcardanol was undoubtedly the CNSL derivative with lowest antioxidant activity among the tested materials. Technical CNSL, on the other hand, was the most effective antioxidant, based on induction period and rate constants. The difference between cardanol and HAlkcardanol activity is small and could be within the range of experimental uncertainty.

\section{Conclusions}

The addition of technical CNSL, cardanol, Hcardanol and HAlkcardanol to synthetic cis-1,4-polyisoprene caused an increase in the induction period and a decrease on the apparent rate constants of thermal oxidation at 140 ${ }^{\circ} \mathrm{C}$. These effects augment with the concentration of added material. However, the antioxidant effectiveness is higher for the addition of $3 \%(\mathrm{~m} / \mathrm{m})$ of $\mathrm{ArOH}$, except for 
HAlkcardanol. This addition provoked an increase of approximately 6, 11, 15 and 38 times in the induction period in the Hcardanol, HAlkcardanol, cardanol and technical CNSL systems, respectively.

All tested material acted as antioxidant for polyisoprene and did not cause the formation of spots. Based on induction period and on apparent rate constants the order of antioxidant activity could be generalized as follows:

CNSL $>>$ cardanol $\cong$ hydrogenated and alkylated cardanol $>$ hydrogenated cardanol.

The more pronounced effect of CNSL could be attributed to the extra contribution of other CNSL components besides cardanol (cardol, 2-methyl-cardol and polymerized material). The higher antioxidant activity of CNSL and cardanol compared with Hcardanol, indicates that the unsaturation on the long side chain could be an important factor. The allyl substituents could trap both alkyl and peroxy radicals, and increase antioxidant activity. The effect of alkylated hydrogenated cardanol is greater than that of nonalkylated cardanol, as expected by the addition of a tert-butyl substituent in the ortho position of the ring.

The concentration of $3 \%(\mathrm{~m} / \mathrm{m})$ of CNSL and derivatives could be considered as too high to be used as an antioxidants. Fortunately, cashew nut shell liquid and derivatives have other useful properties as rubber additives, e.g. as plasticizers, ${ }^{26}$ that in addition to the antioxidant characteristics make the use of CNSL more attractive and of great potencial for industrial applications.

\section{Acknowledgments}

We thank the financial support from CAPES and CNPq.

\section{References}

1. Lubi, M. C.; Thachill, E. B.; Des. Monomers Polym. 2000, 3, 123.

2. Santos, M. L.; Magalhães, G. C.; J. Braz. Chem. Soc. 1999, 10, 13.

3. Kumar, P. P.; Paramashivappa, R.; Vithayathil, P. J.; Rao, P. V. S.; Rao, A. S.; J. Agric. Food Chem. 2002, 50, 4705.

4. Ikeda, R.; Tanaka, H.; Uyama, H.; Kobayashi, S.; Polymer 2002, 43,3475 .
5. Amorati, R.; Lucarini, M.; Mugnaini, V.; Pedulli, G. F.; J. Org. Chem. 2003, 68, 5198.

6. Breese, K. D.; Lamèthe, J. F.; DeArmitt, C.; Polym. Degrad. Stabil. 2000, 70, 89.

7. Matsuura, T.; Ohkatsu, Y.; Polym. Degrad. Stabil. 2000, 70, 59.

8. Menon, A. R. R.; Pillai, C. K. S; Nando, G. B.; J. Appl. Polym. Sci. 1998, 68, 1303.

9. Menon, A. R. R.; Aigbodion, A. I.; Pillai, C. K. S.; Mathew, N. M.; Bhagawan, S. S.; Eur. Polym. J. 2002, 38, 163.

10. Menon, A. R. R.; Pillai, C. K. S.; Nando, G. B.; J. Appl. Polym. Sci. 1999, 73, 813 .

11. Rajapakse, R. A.; Gunasena, W. A. S.; Wijekoon, K. B.; Polymer 1978, 19, 205.

12. Menon, A. R. R.; Pillai, C. K. S.; Nando, G. B.; Polym. Degrad. Stabil. 1996, 52, 265.

13. Rajapakse, R. A.; Anandakumaran, K.; Gunasena, W. A. S.; Wijekoon, K. B.; Polymer 1979, $20,887$.

14. Prasad, V. S.; Pillai, C. K. S.; J. Appl. Polym. Sci. 2000, 77, 2631.

15. Paramashivappa, R.; Kumar, P. P.; Vithayathil, P. J.; Rao A. S.; J. Agric. Food Chem. 2001, 49, 2548.

16. Ricardo, N. M. P. S.; Feitosa, J. P. A.; Silveira, E. R.; Polym. Bull. 2001, 46, 107

17. Alam, T. M.; Celina, M.; Assink, R. A.; Clough, R. L.; Gillen, K. T.; Wheeler, D. R.; Macromolecules 2000, 33, 1181.

18. Lemayev, N. V.; Kurbatov, V. A.; Liakumovich, A. G.; Polymer Science U.S.S.R. 1981, 23, 419.

19. Keen, F. E.; Lehrle, R. S.; Jakab, E.; Szekely, T.; Polym. Degrad. Stabil. 1992, 38, 219.

20. Shadyro, O. I.; Edimecheva, I. P.; Glushonok, G. K.; Ostrovskaya, N. I.; Polozov, G. I.; Murase, H.; Kagiya, T.; Free Radical Res. 2003, 37, 1087.

21. Sokolenko, V. A.; Svirskaya, N. M.; Velikov, A. A.; Sizova, N. V.; Kinet. Catal. 2002, 43, 185.

22. Ohkatsu, Y.; Matsuura, T.; Yamato, M.; Polym. Degrad. Stabil. 2003, 81,151 .

23. Gorghiu, L. M.; Jipa, S.; Zaharescu, T.; Setnescu, R.; Mihalcea, I.; Polym. Degrad. Stabil. 2004, 84, 7.

24. Kim, T. H.; Oh, D. R.; Polym. Degrad. Stabil. 2004, 84, 499.

25. Cibulková, Z.; Simon, P.; Lehocký, B. J.; Polym. Degrad. Stabil. 2005, 87, 479.

26. Menon, A. R. R.; Pillai, C. K. S.; Sudha, J. D.; Mathew, A. G.; J. Sci. Ind. Res. 1985, 44, 324.

Received: August 1, 2005

Published on the web: February 6, 2006 